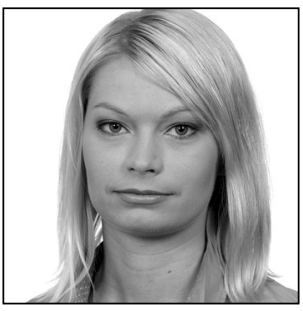

Mari Schihalejev

Doctoral student University of Tartu

\title{
Court Supervision of the Determination of the Votes at the First General Meeting of Creditors in Estonian Bankruptcy Law
}

\section{Introduction}

Creditors' votes have supreme power in bankruptcy proceedings. The creditors have a right to take decisions in the proceedings by using their votes. Those decisions are adopted by a simple majority of the votes of the creditors participating in the meeting. The decisions put to a vote at the first general meeting (hereafter FGM) of creditors constitute the most important issues in the proceedings. These decisions influence the status of the subsequent proceedings, and sometimes this effect may determine the general direction of the proceedings. Hence, it can be said that the process of determining creditors' votes in bankruptcy proceedings is crucial. However, as in many other countries, in Estonian bankruptcy law the process of determining the votes is problematic.

Estonia's first Bankruptcy Act was passed 25 years ago, in 1992, and has been continuously amended. In addition to undergoing several minor amendments, the Bankruptcy Act was amended in its entirety in 1996, 2003, and 2009. ${ }^{*}$ Estonian bankruptcy law has provided three distinct procedures for the determination of votes at the FGM of creditors: 1) the votes are determined only by the trustee; 2) the votes determined by the trustee are approved by the court; or 3) under the current law, the court intervenes only if there is a dispute over the determination of the votes.

One of the main issues over the years, which there have been attempts to resolve, is the problem of determining the votes before the defence of claims. This problem was recognised already in 1993-1994, for the amount of the claim is not clear before the defence of the claims. ${ }^{{ }_{2}}$ However, the number of votes of each creditor corresponds to the amount of the creditor's claim. During preparation of the Bankruptcy Act,

\footnotetext{
P. Varul. Maksejõuetuse areng Eestis ['Developments in insolvency law in Estonia']. - Juridica 2013/4, p. 234 (in Estonian).

2 P. Varul. Selgitavaid märkusi pankrotiseadusele ['Explanatory remarks on the law of bankruptcy']. - Juridica 1993/3, p. 52 (in Estonian). P. Varul. Selgitavaid märkusi pankrotiseadusele ['Explanatory remarks on the law of bankruptcy']. - Juridica 1994/1, p. 6 (in Estonian).
} 
it was stated that the main object of the law is to protect the creditors' interests. ${ }^{*}$ Hence, questions arise as to which procedure for determination of the votes at the FGM of creditors is in the creditors' best interests and what should be the scope of court supervision in keeping with the principle of procedural economy.

In drafting of the Bankruptcy Act, the legislator's objective was that the workload of the courts would be as small as possible. Since the creditors' claims are satisfied out of the bankruptcy estate, they should have been given decision-making power. In drafting of the Bankruptcy Act, the court was entrusted with resolving issues that needed an independent decision-maker. ${ }^{*}$ One of these is the issue of the determination of the votes. However, since the decisions put to a vote at the FGM determine the future course and status of the proceedings, both the court and the trustee play an important role in protecting the common interests of the creditors.

Hence, the law does not set in place clear regulations on how to determine the votes. The disputes are long-term, because there is no regulation of when the court should render its ruling on the determination of the votes so that the FGM could continue. There is also no regulation addressing which disputes should be resolved in the proceedings related to the determination of the votes and which disputes should be resolved in the proceedings related to the defence of the claims.

The objective with this article is to find the answer to the following questions: does the current procedure for the determination of the votes at the FGM of creditors protect the rights and interests of the creditors, which procedure was the best in 1992-2015, does the current procedure protect the common interests of the creditors, and does it follow the principle of procedural economy?

\section{Court supervision of determination of the votes at the FGM of creditors in 1992-2015}

\subsection{The scope of court supervision in 1992-2003}

Since 1992, Estonian bankruptcy law has provided many, different regulations. This stems from the fact that when Estonia regained independence, in the turbulent situation of 1992, a new legal order based on comparative law, on the experiences and legal concepts of other countries, had to be quickly created. A completely new bankruptcy law had to be developed ${ }^{*}$, whereas Estonian civil law has largely Germanic and Swedish roots. ${ }^{* 6}$

The most important reference source for developing Estonia's first Bankruptcy Act ${ }^{*}$ was the Swedish Bankruptcy Act ${ }^{*}$, as the concept of the determination of the votes at the FGM of creditors. According to $\$ 26$ (4) of the BA 1992, the creditors' votes are determined by the trustee. According to subsection 5 of the same provision, if a creditor does not agree on the votes, the votes are determined by the general meeting of creditors. If the creditors do not agree with the meeting's decision, they have the right to file a complaint to the court ( $\$ 27^{1}$ (3) of the BA 1992). However, if the court passes judgement that the general meeting's decision was not justified, then the court declares the general meeting's decision invalid and the votes are determined by the court.

Notwithstanding the existence of disputes over the determination of the votes, the general meeting of creditors was entitled to adopt decisions (\$27 (2) of the BA 1992). If the court decided to decide on a number of votes that differed from the votes determined by the general meeting and this would have resulted

P. Varul. Selgitavaid märkusi pankrotiseadusele ['Clarifying remarks on the law of bankruptcy']. - Juridica 1993/1, p. 6 (in Estonian). P. Varul. Selgitavaid märkusi pankrotiseadusele ['Elucidatory notes on the bankruptcy law']. - Juridica 1994/1, p. 2 (in Estonian).

4 P. Varul. Selgitavaid märkusi pankrotiseadusele ['Explanatory remarks on the law of bankruptcy']. - Juridica 1994/1, pp. 5-6 (in Estonian).

5 P. Varul (see Note 1), p. 234.

6 M. Käerdi. Estonia and the new civil law. - H.L. MacQueen, A. Vaquer, S. Espiau (eds). Regional Private Laws and Codification in Europe. Cambridge 2003, p. 250. - DOI: https://doi.org/10.1017/CBO9780511495007.012.

7 Pankrotiseadus. - RT 1992, 31, 403 (in Estonian).

8 P. Varul. Selgitavaid märkusi pankrotiseadusele ['Clarifying remarks on the law of bankruptcy']. - Juridica 1993/1, p. 6 (in Estonian). P. Varul. Selgitavaid märkusi pankrotiseadusele ['Elucidatory notes on the bankruptcy law']. - Juridica 1994/1, p. 2 (in Estonian). P. Varul. On the development of bankruptcy law in Estonia. - Juridica International 1999 (IV), p. 173. 
in a different decision being adopted, the court declared this decision invalid at the creditors' or trustee's request ( $\$ 27^{1}$ (3) of the BA 1992).

Similarly to Estonian bankruptcy law in force from 1992 to 2003, Chapter 15, Section 3 (3) of the current Finnish Konkurssilaki ${ }^{*} 9$ provides that in the event of disagreement, the estate administrator or, if the matter is discussed at the creditors' meeting, the chairperson decides on the voting strength conferred by a claim. This indicates that the provision on the determination of the votes in the FGM of creditors that was in the Estonian BA in 1992-2003 is possible today.

Although the FGM could continue and votes could be determined at the same meeting, the fact that the bankruptcy trustee determined the number of votes at an early stage essentially alone was considered problematic. The confirmation of the votes determined was not done by the court as an independent person. However, it is incomprehensible why the regulation was considered problematic, because, according to §29 (3) of the BA 1992, the trustee must be independent of the debtor and the creditor. Moreover, the court has not confirmed the votes determined by the trustee since 2010. The same rules and the reasons that were the basis for the amendment of the law turned out to be inaccurate.

Furthermore, the procedure had to be amended because the votes assigned to the creditors determined the power relations between them in the bankruptcy proceedings. ${ }^{*}{ }^{* 10}$ When a dispute arose, the procedure became time-consuming and complex. This, in turn, could lead to the cancellation of the general meeting's decision. Therefore, it was decided to amend the Bankruptcy Act.

\subsection{The scope of court supervision in 2004-2009}

In 2004-2009, the procedure for determination of votes specified in the Bankruptcy Act ${ }^{* 11}$ was radically amended. The bankruptcy judge was involved in the procedure for the determination of the votes. The judge resolved disputes over the votes and also confirmed the votes determined by the trustee. However, a question arose as to whether the judge's confirmation was necessary when there were no disputes over the votes.

If a creditor participating in a general meeting did not agree with the number of votes assigned, the votes were determined by the judge participating in the meeting ( $\$ 82$ (4) of the BA 2004). In such cases, the court resolved the dispute and verified whether there was sufficient basis for the determination of the votes. The law did not prescribe a deadline for the ruling.

The court also made the ruling when there were no disputes over the votes ( $\$ 82(5)$ of the BA 2004). The court confirmed the number of votes determined by the trustee. However, applying the regulation was rather a formality, because in fact the court did not verify the proof of claim, on which basis the votes were determined. The court also did not verify whether the trustee determined the votes in accordance with the principles of protecting the creditors' interests and equal treatment. Nevertheless, the Supreme Court pointed out that in the case of resolving disputes over the votes as well as in the case of confirming the votes, the court should verify the requirements prescribed in $\$ 82$ of the BA. ${ }^{* 12}$ Since court supervision of confirming the votes determined by the trustee was a formality, the act was amended again.

\subsection{The scope of court supervision since 2010}

Since 2010, the procedure for the determination of the votes was supposed to be simpler so that bankruptcy proceedings would go smoothly. ${ }^{* 13}$ According to $\S 82$ (3) of the $\mathrm{BA}^{*}{ }^{* 14}$, the number of votes for each creditor participating in the FGM of creditors is determined by the trustee. According to subsection 4 of the same provision, if a creditor does not consent to the votes as assigned, the votes are determined by a ruling of the

$9 \quad$ Konkurssilaki. - 120/2004 (in Finnish).

10 IX Riigikogu stenogramm. VIII istungijärk. 15. Pankrotiseaduse eelnõu (1085 SE) esimene lugemine ['Report of the proceedings of the IX Riigikogu. VIII session. 15. The first reading of the bill of the Bankruptcy Act']. Available at http://stenogrammid.riigikogu.ee/et/200212041300 (most recently accessed on 23.3.2016) (in Estonian).

11 Pankrotiseadus. - RT I 2003, 17, 95; RT I 2009, 11, 67 (in Estonian).

12 CCSCr 21.4.2005, 3-2-1-42-05, para. 14. Available at http://www.riigikohus.ee/?id=11\&tekst=RK/3-2-1-42-05 (most recently accessed on 23.3.2017) (in Estonian).

13 P. Varul (see Note 1), p. 235.

14 Pankrotiseadus. - RT I 2003, 17, 95; RT I, 22.6.2016, 25 (in Estonian). 
judge participating in the general meeting. An appeal may be filed against such a ruling. However, the law does not provide clear rules for resolving disputes over the determination of the votes. Furthermore, judges participating in the general meetings implement $\$ 82$ (4) of the BA in different ways, which leads to nonuniform court practice. However, it is unclear when the judge will make the court ruling that enables the meeting to continue. Nevertheless, quick and effective proceedings ensure the protection of the creditors' rights and interests.

The current BA does not stipulate which disputes essentially belong to the procedure of determination of the votes; however, the Supreme Court has significantly influenced the development of the bankruptcy law. ${ }^{* 15}$ The Supreme Court stated in case 3-2-1-144-11 that the determination of the number of votes could not be resolved in a dispute that was by nature a dispute over the acceptance of claims. On the other hand, the court stated that such claims could be excluded as obviously and for reason of their legal nature cannot be satisfied in the proceeding. The court gave as an example that the question of the expiry of the claim cannot be resolved in the context of disputes over the votes. However, proofs of claim with formal deficiencies can be disputed, as can proofs of claim in the case of which there have been some legal changes. ${ }^{*} 16$ The Supreme Court's position must be honoured. Otherwise, the bankruptcy proceedings are extended significantly, which is in conflict with the principles of speed and efficiency of proceedings.

Nevertheless, irrespective of the Supreme Court's opinion, most disputes over the determination of the votes are, by nature, disputes over the acceptance of claims. In practice, the number of disputes over the determination of the votes at the FGM has decreased since the Supreme Court's ruling in case 3-2-1-144-11. The ruling may have contributed to uniform application of the bankruptcy law, as in many cases the law does not give an explicit answer. ${ }^{* 17}$ On the other hand, the ruling may lead the trustees to fear that any dispute over the determination of the votes may be a substantive dispute. However, if an objection is not submitted when necessary, the creditors' interests may be harmed.

Furthermore, when a dispute arises, court supervision is quite minimal. However, §82 (4) of the BA, related to disputes over the determination of the votes, has remained unchanged since 2004. The court will be involved only in the event of a dispute over the determination of the votes and exercises supervision over the lawfulness of bankruptcy proceedings. So the court may deny the right to vote, determine the total number of votes, or restrict the number to a partial amount.

In practice, judges do not implement the provisions of $\$ 82$ (4) of the BA properly and do not make the ruling at the same general meeting. According to a literal interpretation of the law and in line with the legislator's objective, the number of votes assigned via a court ruling should be determined immediately at the same meeting. The time it takes to make a ruling depends on the judge. Furthermore, in practice, the FGM does not take place when there are disputes over the determination of the votes. Therefore, bankruptcy proceedings cannot continue, because important decisions are not adopted.

The concept of the determination of the votes by the court under current bankruptcy law is based on the German Insolvenzordnung ${ }^{* 18}$ (InsO). According to $\$ 77$ (2) of the InsO, the judge makes the decision about the determination of the votes immediately at the same meeting. In order for Estonian bankruptcy law to be applied in accordance with the legislator's objective, the provision for the court ruling on the determination of the votes should be rephrased: it should be unambiguous, understandable, and applicable by each judge. The law should prescribe when the court ruling should be issued in cases of disputes. Pursuant to the legislator's objective, the ruling should be made immediately at the same FGM of creditors.

On account of the above, in 1992-2003 the problem was that the creditors' votes were determined only by the trustee. In 2004-2009, the confirmation of the determined votes was a so-called formal process, in which the court did not verify the basis for the determination of the votes. Therefore, §82 (5) of the BA was declared invalid. Therefore, currently the votes are again determined by the trustee, which was found problematic in 1992-2003, and the court intervenes only in the event that there is a dispute.

However, a question arises as to whether the legislator made a reasonable decision by changing §26 (5) of the BA as in force in 1992. It prescribed that if a creditor does not accept the votes, the number of votes is determined by the general meeting of creditors, and this enabled the meeting to continue. However, in

15 P. Varul (see Note 1), p. 235.

16 CCSCr 10.1.2012, 3-2-1-144-11, para. 14. Available at http://www.riigikohus.ee/?id=11\&tekst=RK/3-2-1-144-11 (most recently accessed on 23.3.2017) (in Estonian).

17 P. Varul (see Note 1), p. 235.

18 Insolvenzordnung vom 5 Oktober 1994. - BGBl. I p. 2866 (in German). 
consideration of $\S 82$ (4) of the current act, the problem may in practice result from the fact that judges are not implementing the law pursuant to the legislator's objective. It has been stated in the literature that problems encountered in the implementation of the bankruptcy law can be divided into two groups: problems that can be solved by means of interpretation and problems that can be solved only by amendment of the law. ${ }^{{ }^{*} 9}$ Current practice indicates that the solution is to amend the law.

The law should prescribe the term for the court ruling. However, there is also the problem of which issues belong to the sphere of disputes over the votes. The nature of disputes over the votes cannot be stated in legislation, so it must be established by court practice. Prescribing the term by law and making court practice uniform enables ensuring the creditors' rights and interests while also rendering the proceedings quick and effective.

\section{The basis for determination of the number of votes}

If a creditor submits the proof of claim together with documents proving the circumstances to the trustee, a dispute over the determination of the votes does not arise. However, in practice, there are a lot of problems related to which documents must be submitted for obtaining votes at the FGM.

Creditors assigned votes at the FGM must file proper proof of claim with the trustee on time. Pursuant to $\S 94$ (1) of the BA, the trustee is notified of a claim by proof of claim. The proof of claim should set out the content of, basis for, and amount of the claim and whether the claim is secured by a pledge. Documents proving the circumstances specified in the proof of claim should be annexed thereto. According to subsection 3, when the proof of claim is not properly prepared, the trustee grants a term of at least 10 days for elimination of the deficiencies. When the deficiencies nonetheless are not eliminated, the general meeting of creditors may deem the proof of claim not to have been submitted.

Although the law provides formal requirements for the proof of claim, in cases of more complex legal relationships, the creditor should also substantiate the proof of claim in order to obtain votes from the trustee at the FGM. Nevertheless, the Supreme Court has taken a different position on which documents should be filed with the trustee before the FGM of creditors.

The Supreme Court has stated, in civil case 3-2-1-8-15, that the proof of claim filed should provide information about the claim's content and basis and shall also state the amount of the claim and whether it is secured by a pledge. The Supreme Court also stated that, depending on the circumstances, it may be appropriate to annex the documents proving the claim (i.e., which substantiate the claim), in order to avoid ambiguity and subsequent disputes. Despite the fact that terms are given in the law, the Supreme Court states that if documents proving the circumstances are not annexed to the proof of claim, there is no basis for the general meeting of creditors to deem proof of claim not to have been submitted. The documents proving the claim may be submitted up to the time of the court proceedings for the defence of the claims. ${ }^{*}$

The author of this article does not agree with the Supreme Court's position. To obtain votes at the FGM of creditors, the creditor must submit all documents proving the claim. Otherwise, the creditor may obtain votes and have an important position in the bankruptcy proceedings while possibly not, in fact, having a claim against the debtor. It is not - and cannot be - the legislator's objective to assign votes to a creditor who has not proved the claim against the debtor.

Furthermore, pursuant to $\$ 55$ (1) of the BA, the trustee protects the rights and interests of all creditors and of the debtor and ensures a lawful, prompt, and financially reasonable bankruptcy procedure. Protection of the creditors' interests is the trustee's common obligation. ${ }^{* 21}$ The trustee cannot determine the votes unless the proof of claim is sufficiently substantiated: it must be clear, understandable, and verifiable. Pursuant to $\$ 235$ of the Code of Civil Procedure ${ }^{*_{22}}$ (CCP), substantiation of an allegation means giving the court reasons for that allegation so that, presuming that the reasoning is correct, the court can deem the allegation to be plausible. The creditor must eliminate potential conflicts and ensure sufficient clarity of the proof of claim. The creditor is required to submit all the information necessary for the trustee to identify the

19 P. Varul. Pankrotiõiguse probleeme ['Issues concerning bankruptcy law']. - Juridica 1999/8, p. 376 (in Estonian).

20 CCSCr 8.4.2015, 3-2-1-8-15, para. 12. Available at http://www.riigikohus.ee/?id=11\&tekst=RK/3-2-1-8-15 (most recently accessed on 23.3.2017) (in Estonian).

21 P. Varul. Nõuetest pankrotimenetluses ['Claims in bankruptcy proceedings']. - Juridica 2004/2, p. 98 (in Estonian).

22 Tsiviilkohtumenetluse seadustik. - RT I 2005, 26, 197; RT I, 28.12.2016, 22 (in Estonian). 
claim. The trustee must be able to make sure readily whether the creditor has a claim against the debtor. Unclear proof of claim is not justified by $\S 94$ (1) and $§ 82$ (4) of the BA, and, hence, the creditors have no just cause to obtain the votes.

Furthermore, the essential documents supporting the claim should be submitted to the trustee not later than three working days before the general meeting, to give the trustee sufficient time to verify whether the proof of claim corresponds to the requirements prescribed by $\S 94$ (1) of the BA. Otherwise, the term for verifying the documents would not be prescribed in the law. According to $\S 94$ of the BA, it is an important element of the proof of claim that it must be supplemented with documents proving the circumstances.

Because of the above, a creditor assigned votes at the FGM must submit proper proof of claim to the trustee in three working days. This gives the trustee sufficient time to verify whether the claim is in accordance with the requirements prescribed by law. In addition to formal requirements pertaining to the proof of claim, documents proving the specified circumstances must be annexed thereto, for avoidance of disputes over the votes.

\section{The efficiency aspect: Implementation of the principles of speed and efficiency in making the ruling on the determination of the number of votes}

The purpose of civil procedure is to guarantee adjudication of civil matters by the court within a reasonable period of time ( $\$ 2$ of the CCP). Bankruptcy proceedings should also be conducted as quickly and efficiently as possible. The proceedings should be addressed and resolved in an orderly, quick, and efficient manner and with minimal costs. ${ }^{{ }_{23}}$ In the literature, it has been stated that quick bankruptcy proceedings are effective. ${ }^{* 24}$ Accordingly, the question arises of how to ensure fast and effective proceedings in cases of disputes over the determination of the votes, with the aim of protecting the creditors' rights and interests.

The bankruptcy proceedings can be carried out quickly if there are no disputes over the votes. However, achieving ideal bankruptcy proceedings is difficult. As mentioned before, in a case involving a dispute, the time for making the ruling about the votes may differ, depending on the judge. Some county court judges take a break at the FGM of creditors and determine the votes immediately. However, other judges determine the votes at the follow-up general meeting, which might take place in the same week or even a few months later. In the interim period, the meeting will generally not be continued and decisions will not be adopted. If an appeal is made against such a ruling to the district court and to the Supreme Court, the FGM will not be continued until the ruling is in force. However, when the meeting will continue despite the dispute over the votes, this may give rise to another dispute. According to $\$ 83$ (1) of the BA, the court may, if the creditors' common interests are harmed, revoke the decisions adopted. ${ }^{* 25}$

The author of this article can cite some cases involving the determination of the votes in Estonian practice. The objective for presenting the cases is to indicate how long the process of determination of the votes by a judge could be. A lenghty process of determination of the votes makes bankruptcy proceedings inefficient, whereas the proceedings should be as quick as possible.

In civil case 2-10-59818, a dispute over the determination of the votes was appealed to the Supreme Court. The FGM of creditors took place on 2.2.2011. Creditors participating in the meeting did not agree with the number of votes assigned by the trustee. Harju County Court made a ruling on the determination of the votes on 2.3.2011. ${ }^{*}$ Since Harju County Court dismissed the appeal, it was sent to Tallinn District Court, which issued a ruling on 28.6.2011. ${ }^{* 27}$ The ruling was also appealed to the Supreme Court. The Supreme Court made a ruling in case 3-2-1-144-11 on 10.1.2012 and sent the case back to the county

23 United Nations Commission on International Trade Law (UNCITRAL). Legislative Guide on Insolvency Law, p 12. Available at http://www.uncitral.org/pdf/english/texts/insolven/05-80722_Ebook.pdf (most recently accessed on 6.12.2015).

24 T. Saarma. Pankrotimenetluse põhimõtted. ['The principles of bankruptcy law']. - Juridica 2008/6, p. 353 (in Estonian).

25 CCSCr 15.4.2015, 3-2-1-27-15, para. 14. Available at http://www.riigikohus.ee/?id=11\&tekst=222577856 (most recently accessed on 23.3.2017) (in Estonian). CCSCr 10.6.2015, 3-2-1-59-15, para. 12. Available at http://www.riigikohus. ee/?id=11\&tekst=RK/3-2-1-59-15 (most recently accessed on 23.3.2017) (in Estonian).

26 Ruling of Harju County Court 2-10-59818 (in Estonian).

27 Ruling of Tallinn District Court 2-10-59818 (in Estonian). 
court for a new hearing. ${ }^{* 28}$ The county court made a ruling within two weeks after the general meeting, but the district court issued its ruling about four months after the county court's ruling. The Supreme Court's ruling, in turn, was made almost six months after the ruling of the district court. In this case, it took almost one year to resolve the dispute over the determination of the votes. This duration for such a fundamentally important dispute as that over determination of the votes, on which the entire future of the bankruptcy proceedings depends, is in conflict with the principles of speed and efficiency.

Furthermore, in civil case 2-13-32716, wherein the FGM of creditors was held on 23.10.2013, the trustee did not determine the votes for some creditors, and Harju County Court made a ruling on the matter on 5.11.2013. ${ }^{*} 2$ This was two weeks after the first meeting of creditors was held. The creditor appealed against the ruling to Tallinn District Court, which issued its ruling about the votes on 31.3.2014. ${ }^{*} 30$

In civil case 2-13-13251, the FGM of creditors was held on 4.2.2014. The trustee determined the votes for each creditor proportionally to the amount of the creditor's claim pursuant to $\$ 82$ (1) of the BA. The creditors filed an appeal against the votes assigned, on the basis of \$82 (4) of the BA. Harju County Court made a ruling on 20.2.2014. ${ }^{*}{ }^{11}$ This was two weeks after the first meeting of creditors was held. An appeal was filed with the district court. Tallinn District Court made a ruling on 10.5.2014, in accordance with which the county court's ruling was not changed. ${ }^{*} 32$ The ruling was appealed to the Supreme Court. Harju County Court's decision came into force on 10.6.2014. Thus, this civil case was settled four months after the FGM of creditors.

In civil case 2-15-13938, the FGM of creditors took place on 24.11.2015 and on 11.12.2015. The court determined the votes on 18.12.2015, because some creditors did not agree with the votes determined by the trustee. ${ }^{*} 33$ One of the creditors filed an appeal against the ruling. However, the court refused to accept that appeal on 17.2.2016. ${ }^{*} 34$ The court stated at the FGM that the meeting would continue when the court ruling enters into force. Although the ruling entered into force on 12.3.2016, the court decided that the FGM of creditors was to take place on 17.6.2016. Hence, even though the ruling about the votes entered into force on 12.3.2016, the FGM was still held three months later.

Although only a few cases are presented in this article, they provide sufficient proof that the determination of the votes is a long-term process. It can, however, be said that since 2011 the amount of time taken for settling disputes over the votes determined has decreased. Nevertheless, by the time the ruling has come into force, some important deadlines might have passed. Therefore, it would be wise to specify a term within which the county court, district court, and Supreme Court must resolve disputes over the determination of the votes and determine the date for the FGM of creditors. After all, the legislator's objective was that the votes be determined by the county court ruling immediately, at the same meeting.

Furthermore, the creation of specialised insolvency courts, which has also been considered for establishment in the Estonian insolvency law, might help to enhance the efficiency of insolvency proceedings. ${ }^{*}{ }^{35}$ The World Bank has drawn attention to the fact that insolvency courts ensure quick proceedings, which, in turn, enable obtaining the best value for the property. ${ }^{*} 6$ The Cork Committee too opines that bankruptcy courts are important. ${ }^{*} 37$ The bankruptcy courts do not have a heavy workload of other civil cases, and urgent disputes over the determination of the votes could be resolved within reasonable time. Therefore, with the existence of bankruptcy courts, a case could be settled 'ASAP', which would ensure that the principles of speed and efficiency of the procedure are followed.

On account of the above, the court must ensure prompt and effective bankruptcy proceedings, to resolve the dispute within a reasonable amount of time. In accordance with the legislator's objective, the ruling

\footnotetext{
CCSCr 10.1.2012, 3-2-1-144-11.

Ruling of Harju County Court 2-13-32716 (in Estonian).

Ruling of Tallinn District Court 2-13-32716 (in Estonian).

1 Ruling of Harju County Court 2-13-13251 (in Estonian).

Ruling of Tallinn District Court 2-13-13251 (in Estonian).

Ruling of Tallinn County Court 2-15-13938 (in Estonian).

Ruling of Tallinn County Court 2-15-13938 (in Estonian).

P. Varul (see Note 1), p. 236.

36 The World Bank. Principles and Guidelines for Effective Insolvency and Creditor Right Systems. April 2001, pp. 56-57. Available at http://www.worldbank.org/ifa/ipg_eng.pdf (most recently accessed on 6.12.2015).

37 K. Kerstna-Vaks. Järelevalve pankrotimenetluses ['Supervision over bankruptcy proceedings'], p. 52. Master's thesis, Tartu 2005 (in Estonian).
} 
about the votes should be made at the same FGM immediately, when the dispute arises. A major problem in court practice may be resolved by prescribing the term in the act that states when the dispute should be settled, so that the judges would implement the provision properly. Furthermore, to ensure that disputes are resolved within reasonable time and that the principles of speed and efficiency are followed, insolvency courts should be created. Doing so protects the common interests of the creditors.

\section{The fairness aspect: The creditors' real purpose in submitting the proof of claim}

As mentioned above, in accordance with $\$ 94$ (1) of the BA, a creditor wishing to have the right to vote at the FGM of creditors is required to submit proper proof of claim three working days before the meeting. Nevertheless, although the creditors may have submitted a proper claim, its purpose might be contrary to the objective of bankruptcy proceedings and to good faith. However, in the literature it has been stated that legal rules as rules that regulate human behaviour should be based on the most important idea of the law on justice. ${ }^{*} 38$ Furthermore, ius est ars boni et aequi. ${ }^{*} 39$

In spite of that, some creditors may participate in insolvency proceedings in order to adopt decisions at the creditors' meeting whereby they wrongfully obtain funds recovered during the insolvency proceedings. In civil case 3-2-1-27-15, the Supreme Court stated that creditors cannot be allowed to contest the votes for tactical reasons. This would lessen the possibility of carrying out the bankruptcy proceedings within a reasonable period of time and of protecting all the common interests of the creditors by means of smooth proceedings. ${ }^{*} 40$

Pursuant to $\S 138$ (1) of the General Part of the Civil Code Act ${ }^{*} 41$, rights are to be exercised and obligations are performed in good faith. Even in application of provisions that are not in direct conflict with the legislation, acting for such a purpose may be unlawful. This is confirmed by $\$ 138$ (2) of the General Part of the Civil Code Act: a right shall not be exercised in an unlawful manner or with the objective of causing damage to another person. Also, §200 (1) of the CCP prescribes that a participant in a proceeding is required to exercise the procedural rights in good faith, and subsection 2 states that participants in a proceeding and their representatives or advisers are not allowed to abuse their rights, delay the proceeding, or mislead the court.

Furthermore, if the creditor is a person connected with the debtor as defined in $\S 117$ of the BA, it is justified to apply stricter requirements for verification and substantiation of the claim. In the case of relatedparty transactions as well as in circumstances wherein the transaction is made by one and the same person, the trustee must pay more attention to the verification and determination of the votes (Harju County Court ruling No. 2-13-32716, from 5.12.2013). In the literature, it has even been stated that specific terms on the determination of the votes assigned to persons connected with the debtor should be imposed. However, Estonian bankruptcy law does not prescribe specific regulation on creditors connected with the debtor.

Consequently, in order to reach the objective of the law, the trustee, in co-operation with the court, has the right and obligation to verify and evaluate the documents substantiating the claim in order to prevent unjustified claims (for example, due to ostensible transactions) from conferring control over the bankruptcy proceedings. A system that is fair on and equitable to the creditors must be enforced.

\section{Conclusions}

In conclusion, Estonian bankruptcy law has had three totally different regulations on the determination of the votes at the FGM of creditors in bankruptcy proceedings. In 1992-2003, the problem was that the creditors' votes were determined only by trustee. Therefore, in 2004-2009 the judge was involved. However, the confirmation of the votes determined was a formal process, in which the court did not verify the bases

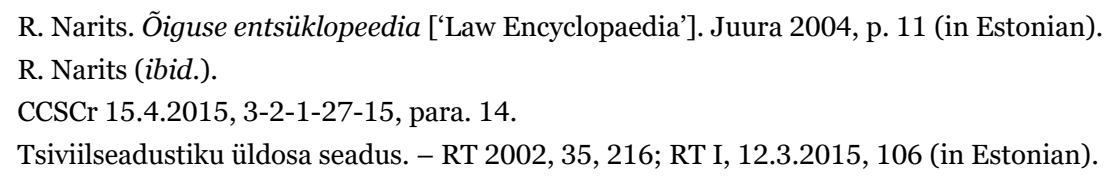


for the determination of the votes. Hence, nowadays the votes are again assigned by the trustee, which had been found problematic in 1992-2003. Moreover, the court intervenes only in the event of a dispute over the determination of the votes. However, the disputes are long-term, and, therefore, the FGM of creditors is held several months or even a year after the initial FGM. In contrast, bankruptcy proceedings should be as quick and efficient as possible. The current procedure for the determination of the votes at the FGM of creditors does not protect the rights and interests of the creditors, does not protect the common interests of the creditors, and does not follow the principle of procedural economy.

Hence, current legislation on the determination of the votes at the FGM of creditors is not perfect. However, none of the regulations that have been in force since 1992 have been perfect as regards the protection of the creditors' common interests and the principle of efficiency. In fact, it seems that the legislator did not make a reasonable decision by changing $\$ 26$ (5) of the BA as in force in 1992. That provision prescribed that if a creditor does not consent to the number of the votes assigned, the votes are determined by the general meeting of creditors. This regulation ensured that the meeting could continue immediately. It did protect the creditors' common interests, because the bankruptcy proceedings could continue. However, in case of a dispute, the decisions adopted could be changed by the judge. Therefore, resolving the dispute was time-consuming and complex, and when the dispute over the votes was opened in court, application of the principle of procedural economy was affected.

Considering §82 (4) of the current BA, one finds that the actual problem in practice results from the fact that judges are implementing the law in a way that deviates from the legislator's objective. The court must ensure prompt and effective bankruptcy proceedings, to resolve the dispute within reasonable time. The ruling on the votes should be made immediately at the same FGM. Therefore, the law should provide a term that specifies the time by which court rulings on the determination of the votes should be made. Important decisions thus could be adopted at the same general meeting, and bankruptcy proceedings could continue. Furthermore, to ensure that disputes are resolved within reasonable time and that the principles of speed and efficiency are honoured, insolvency courts should be created.

There is also the problem of determining which issues belong to the disputes about votes. However, as the nature of the disputes over the votes cannot be stated in the law, it must be established by court practice. In order to reach the objective of the law, the trustee, in co-operation with the court, has the right and obligation to verify and evaluate the documents substantiating the claim in order to prevent unjustified claims from conferring control over the bankruptcy proceedings. A creditor assigned votes at the FGM must file proof of claim, together with documents proving the circumstances, with the trustee in three working days. In order to protect the creditors' interests, a fair and equitable system must be employed. 